\title{
Stimulation of hCG protein and mRNA in first trimester villous cytotrophoblast cells in vitro by glycodelin $A$
}

\author{
Udo Jeschke ${ }^{1, *}$, Uwe Karsten², Toralf Reimer ${ }^{3}$, \\ Dagmar-Ulrike Richter ${ }^{3}$, Claudia Bergemann ${ }^{3}$, \\ Volker Briese ${ }^{3}$, loannis Mylonas ${ }^{1}$ and Klaus \\ Friese ${ }^{1}$ \\ ${ }^{1}$ Ludwig Maximilians University of Munich, Department \\ of Obstetrics and Gynecology, Munich, Germany \\ ${ }^{2}$ Max Delbrück Centre for Molecular Medicine, \\ Berlin, Germany \\ ${ }^{3}$ University of Rostock, Department of Obstetrics and \\ Gynecology, Rostock, Germany
}

\begin{abstract}
Aim: Human chorionic gonadotropin (hCG) is produced by fetal trophoblast cells and secreted into maternal circulation mainly in the first trimester of pregnancy. Another glycoprotein, glycodelin $A$, is one of the main products of the maternal decidua during this period. The purpose of this study was to investigate the effect of glycodelin A on hCG release by isolated cytotrophoblast cells in vitro. Methods: Cytotrophoblast cells were prepared from human first trimester placenta and incubated with varying concentrations of glycodelin A. Supernatants were assayed for hCG protein concentrations, and quantification of beta hCG mRNA was carried out by RT-PCR. Expression of hCG was analysed in stimulated trophoblast cells and in unstimulated controls by immunocytochemistry.
\end{abstract}

Results: Glycodelin A induces a dose-dependent increase of $h C G$ production. An increase of hCG expression was measured at 100 and $200 \mu \mathrm{g} / \mathrm{mL}$ glycodelin-A treatment in trophoblast cell culture by TaqMan assay on mRNA level. We found a moderate staining of $h C G$ in control trophoblast cells, whereas a strong hCG staining was seen in glycodelin A-treated trophoblast cells.

Conclusions: $\mathrm{HCG}$ is a marker for the differentiation process of trophoblast cells. Our results suggest that glycodelin A secreted by the decidualized endometrium is involved in the regulation of hormones produced by the trophoblast.

\footnotetext{
${ }^{*}$ Corresponding author.

PD Dr. Udo Jeschke

Ludwig Maximilians University of Munich

Department of Obstetrics and Gynaecology

Maistrasse 11

80337 Munich

Germany

Tel.: + 49-89-5160-4266

Fax: + 49-89-5160-4916

E-mail: udo.jeschke@fk-i.med.uni-muenchen.de
}

Keywords: First trimester villous cytotrophoblast cell culture; glycodelin A; regulation of hCG.

\section{Introduction}

Glycodelin, previously known as placental protein 14 (PP14), is expressed in glandular epithelium of the endometrium [20] and decidua [19]. Glycodelin suppresses the cytolytic capacity of NK-cells (Natural Killer Cells) in vitro [32] and it stimulates the Th2-type cytokine production in monocytes [28], shown by an increased production of IL-6 and IL-10 following glycodelin exposure $[25,26]$. Glycodelin directly inhibits T cell activity [39] in an early phase of activation by diminishing $T$ cell responses in the contact site at the time of $\mathrm{T}$ cell receptor triggering and inducing $T$ cell apoptosis [38]. Our own investigations [48] suggest a relationship between serum levels of PP14 and threatened abortion, whereby serum PP14 levels were significantly lower in patients with threatened abortion at 10 to 20 weeks of gestation than in normal pregnancies. Glycodelin was shown to have a molecular weight of $28 \mathrm{kDa}$ with two identical subunits held together by non-covalent bonds and a carbohydrate content of $17.5 \%$ with a unique carbohydrate configuration. Glycodelin, isolated from amniotic fluid (glycodelin A, GdA), contains fucosylated LacdiNAc structures that are very unusual for mammals [8]. Julkunen and co-workers confirmed the homology between GdA and $\beta$-lactoglobulins by deducing its complete amino acid sequence [22]. A similar glycoprotein, glycodelin $\mathrm{S}$, is found in seminal plasma, but it is differentially glycosylated from GdA [23].

It is assumed that GdA plays an important role during implantation and the early survival of the developing fetoplacental unit. GdA serum levels increase on the 14th day after conception but do not differ from levels in the late secretory phase [21]. A more significant rise of glycodelin A has been found on the 21st and 28th day of pregnancy. The highest serum glycodelin A concentrations have been detected between six and 12 weeks of gestation, followed by a decrease and plateau at 24 weeks. Julkunen et al. [21] measured the content of GdA in amniotic fluid and found the highest values between the 12th and 20th week of gestation with a highest level of $232 \mu \mathrm{g} / \mathrm{mL}$. This is nearly one thousand fold higher than the serum glycodelin $\mathrm{A}$ for equivalent gestational age. Even early radioimmunoassays established that the GdA secretory pattern resembles that of human chorionic 
gonadotropin (hCG) [42]. Because these two proteins are different with regards to their tissue of origin (GdA is produced by maternal decidua but hCG is produced by fetal trophoblast), no functional relationship between $\mathrm{hCG}$ and $\mathrm{GdA}$ is suggested. It is generally accepted that $\mathrm{hCG}$ is produced by the syncytiotrophoblast [45], but Hoshina et al. [12] and Boime [3] speculated that hCG could also be produced by cytotrophoblast cells, although the regulation of placental hCG- $\beta$ expression is still not well understood [27]. In a preliminary study we investigated the expression of $\beta \mathrm{hCG}$ mRNA in panels of different human normal tissues and isolated term trophoblast cells [40]. We found a $\beta$ hCG stimulation by glycodelin A on mRNA level. The effect of glycodelin A on $\beta$ hCG regulation is time-dependent. We observed a short increase of $\beta$ hCG mRNA copy numbers 60 min after glycodelin A treatment. In another study, normal preparations of human term trophoblast cells in vitro were used to investigate the effect of glycodelin $\mathrm{A}$ on endocrine trophoblast function by measuring the release of $h C G$ in culture medium [17]. Because production of both GdA and hCG are highest in the first trimester of pregnancy, we undertook the present study to investigate the influence and relationship of glycodelin A on BhCG-mRNA and protein expression in isolated first trimester trophoblast cells.

\section{Materials and methods}

Placental tissue was obtained from terminations of normal pregnancies between the seventh and $12^{\text {th }}$ week of gestation. A total of 14 placentas was obtained after curettage treatment. All women were between 22 and 36 years, had a singleton pregnancy and showed no abnormalties until the moment of termination. The study was approved by the ethical committee of the University of Rostock, and informed consent to use the tissue was obtained from each patient.

Dulbecco's modified Eagle's medium (DMEM), Hank's balanced salt solution (HBSS) without $\mathrm{Ca}^{2+}$ and $\mathrm{Mg}^{2+}$, antibiotic and antimycotic solutions, Ultroser $G$ and trypsin-EDTA were obtained from GibcoBRL Life Technologies (Paisley, UK). Trypsin type 3 and DNAse I were obtained from Sigma (Taufkirchen, Germany) and HEPES buffer $(1 \mathrm{M})$ and inactivated fetal calf serum (FCS) came from Biochrom (Berlin, Germany).

\section{Preparation and culture of villous cytotrophoblast cells}

CTBs were prepared according to a published protocol [15]. Briefly, first trimester placental tissue was minced and digested three times with trypsin and DNAse I in HBSS-HEPES. First purification was performed on a percoll gradient. After centrifugation, CTBs were aspirated and the villous cytotrophoblast cells were immunopurified using antibodies against CD45 and CD9 (Dianova, Hamburg, Germany) and a magnetic cell sorting column (Miltenyi Biotec $\mathrm{GmbH}$, Bergisch Gladbach, Germany) to eliminate contaminating leukocytes (CD45), extravillous trophoblast cells, fibroblasts and other mesenchymal components (CD9). The identity of the isolated villous cytotrophoblast cells was determined morphologically by light microscopy and by immunostaining with a monoclonal mouse anti-cytokeratin 7 antibody (Progen Biotechnik, Heidelberg, Germany). In addition, cells were checked for possible expression of the Thomsen-Friedenreich epitope, which is a marker for syncytiotrophoblast [15]. Isolated cells contained less than 1\% digested fragments of the syncytiotrophoblast. Cells were cultured in DMEM medium with $10 \%$ inactivated FCS and with antibiotics and antimycotics.

\section{Purification of glycodelin A from amniotic fluid}

Glycodelin A was purified from amniotic fluid obtained from the pooled samples obtained from women with normal singleton pregnancies that for diagnostic purposes by two anion exchange chromatography steps, gel filtration and two hydrophobic interaction chromatography steps as described elsewhere [17]. Briefly, amniotic fluid was loaded onto a DEAE-Sepharose column and fractionated on a 50-500 mm $\mathrm{NH}_{4} \mathrm{HCO}_{3}$-gradient followed by gel filtration and a second anion exchange chromatography step on Resource Q. Final purification was obtained by hydrophobic interaction chromatography on Octyl-Sepharose and Resource-Phe (all columns by Amersham Pharmacia Biotech AB, Uppsala, Sweden).

\section{Identification of glycodelin A by Western blot analysis}

Western blot analysis of purified glycodelin A was carried out according to the procedure published elsewhere [2]. Briefly, glycodelin A was detected with a polyclonal rabbit anti glycodelin A antibody (10 $\mu \mathrm{g} / \mathrm{mL}$, Bioscience, Berlin, Germany) followed by anti-rabbit IgG conjugated to HRP (1:1000, Dianova, Hamburg, Germany) and stained with 3-amino-9-ethyl carbazol (Sigma).

\section{Treatment of trophoblast cultures with glycodelin A}

Freshly isolated trophoblast cells were incubated at concentrations of $1 \times 10^{6}$ cells $/ \mathrm{mL}$ in 24-well plates (Greiner Labortechnik, Solingen, Germany) in humidified $5 \% \mathrm{CO}_{2}-95 \%$ air at $37^{\circ} \mathrm{C}$ in the presence of $50 \mu \mathrm{g} / \mathrm{mL}, 100 \mu \mathrm{g} / \mathrm{mL}$ and $200 \mu \mathrm{g} / \mathrm{mL}$ glycodelin A. Untreated cell cultures of the same placentas were used as controls. In addition, samples of the transferrin containing fraction of amniotic fluid were also used as controls to verify the effect of glycodelin A. The effect of glycodelin A on the secretion of markers for syncytiotrophoblasts was studied by comparing the kinetics of hCG mRNA or protein production of untreated (controls) and glycodelin A-stimulated trophoblast cell cultures simultaneously. All experiments were carried out at least in triplicates.

\section{Identification of hCG $\beta$-mRNA transcripts (real-time RT-PCR)}

Total RNA was prepared using the acid guanidium thiocyanatephenol-chloroform protocol [6]. Quality of the RNA samples was determined by electrophoresis through denaturing agarose gels and staining with ethidium bromide. The RNA was quantified and evaluated for purity by UV spectrophotometry. To further assess the quality of RNA, all specimens were tested by analysis of housekeeping gene expression using conventional RT-PCR.

HCG- $\beta$ primers and probe were designed using the Primer Express $^{\text {TM }} 1.0$ program (PE Applied Biosystems, Foster City, CA). 
Oligonucleotide hybridisation probe and primers with the following sequences were synthesized as follows: TaqMan ${ }^{\mathrm{TM}}$ probe $5^{\prime}$ CTG CTG AGC ATG GGC GGG ACA T (exon 2), forward primer 5'-CCA AGG ATG GAG ATG TTC CAG, and reverse primer 5'GCA CGC GGG TCA TGG T. The reverse primer was designed to span an exon/intron junction to avoid amplification of DNA sequences, whereas the forward primer was complementary to the $3^{\prime}$-end of exon 1. Primers and probe were obtained from Applied Biosystems GmbH (Weiterstadt, Germany). The primers yielded a RT-PCR product of 199 nucleotides [40].

The preparation of RNA standard and quantification of $\beta \mathrm{hCG}$ mRNA expression by ABI PRISM 7700 Sequence Detection System (PE Applied Biosystems) have been published in detail previously $[40,41]$. The TaqMan ${ }^{\circledR}$ EZ RT-PCR Kit (PE, Applied Biosystems) was used for reverse transcription and amplification of both targets and standards. All RT-PCR reactions were performed in triplicate with a final volume of $25 \mu \mathrm{L}$. RT-PCR conditions were optimised for primers (300 nM), probe (100 nM), template (100 ng), and manganese acetate concentrations ( $3 \mathrm{~mm}$ ). The reaction conditions were $2 \mathrm{~min}$ at $50^{\circ} \mathrm{C}, 30 \mathrm{~min}$ at $60^{\circ} \mathrm{C}, 2 \mathrm{~min}$ at $95^{\circ} \mathrm{C}, 40$ cycles with $20 \mathrm{sec}$ at $94^{\circ} \mathrm{C}$ and $1 \mathrm{~min}$ at $60^{\circ} \mathrm{C}[41]$.

\section{Analysis of hCG protein production}

At designated times ( $24 \mathrm{~h}$ and $48 \mathrm{~h}$ ) aliquots of the culture media were taken, frozen at $-40^{\circ} \mathrm{C}$ and replaced with fresh medium. Cells were cultured for up to $48 \mathrm{~h}$. Secretion of hCG was analysed by the automated hormone analyser "Immulite" (DPC Biermann $\mathrm{GmbH}$, Bad Nauheim, Germany). This assay detects, besides normal hCG, the five irregular forms of $\beta$ hCG including hyperglycosylated hCG. The results of this assay agree with those of the RIA, and it avoids false-positive values in the samples tested [7]. The sensitivity of the used assay is $1.1 \mathrm{mIU} / \mathrm{mL}$, and the detection limit is $5000 \mathrm{mlU} / \mathrm{mL}$.

\section{Immunocytochemistry}

Isolated trophoblast cells were incubated with varying concentrations of glycodelin $(0,100 \mu \mathrm{g} / \mathrm{mL}$ and $200 \mu \mathrm{g} / \mathrm{mL})$ and grown on three-well multitest slides (Roth, Karlsruhe, Germany) for up to $72 \mathrm{~h}$. At designated times, medium was withdrawn, the slides were air-dried, wrapped and stored at $-80^{\circ} \mathrm{C}$. After thawing, the cells were briefly fixed with formalin (Merck, Darmstadt, Germany; $5 \%$ in PBS, 5 min) and permeabilized with digitonin (Ysat, Wernigerode, Germany; $6 \mu \mathrm{g} / \mathrm{mL}$ in PBS, $15 \mathrm{~min})$. The antibody against hCG was diluted to $5 \mu \mathrm{g} / \mathrm{mL}$ with PBS and incubated with the slides overnight at $4^{\circ} \mathrm{C}$. As isotype controls of the antihCG antibody normal mouse serum as well as a monoclonal antibody against Glycodelin A (A87-B/D2, IgG) were incubated with different slides overnight at $4^{\circ} \mathrm{C}$. After washing, Cy3labelled goat anti-mouse $\operatorname{lgG}$, diluted 1:200, were used as second antibodies for staining of hCG. Slides were examined with a Zeiss (Jena, Germany) Axiophot photomicroscope. Digital images were obtained with a digital camera system (Axiocam; Zeiss) and saved on computer.

\section{Statistical analysis}

The SPSS/PC software package, version 6.01 (SPSS GmbH, Munich, Germany), was used for collection, processing, and sta-
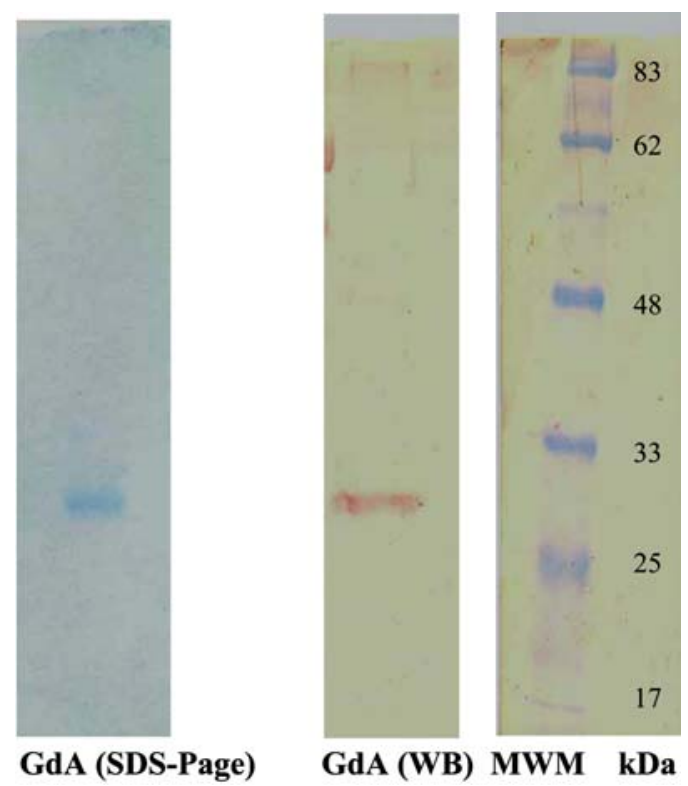

Figure 1 SDS-PAGE analysis of glycodelin A (lane 1, stained with Coomassie Brillant Blue G250, Amersham Biosciences), lane 2; glycodelin A, Western blot analysis detected with a polyclonal glycodelin antibody (Bioscience), lane 3; protein marker (New England Biolabs)

tistical analysis of all data. Statistical analysis was performed using the non parametrical Wilcoxon's signed rank tests for comparison of the means. $\mathrm{P}<0.05$ was considered statistically significant.

\section{Results}

\section{Purification of glycodelin A from amniotic fluid}

SDS-PAGE of the purified protein showed one band at $28 \mathrm{kD}$ (Figure 1, Lane 1). In addition, the purified protein was checked for impurities of hCG by the automated hormone analyser "Immulite" (DPC Biermann GmbH, Bad Nauheim, Germany) and did not contain any hCG traces. Identity of purified glycodelin A was checked by Western blot analysis (Figure 1, Lane 2).

\section{Stimulation of hCG $\beta-m R N A$ production by glycodelin A}

An increase of hCG $\beta-m R N A$ expression was measured at $100 \mu \mathrm{g} / \mathrm{mL}$ and $200 \mu \mathrm{g} / \mathrm{mL}$ glycodelin A-treatment in trophoblast cell cultures by the TaqMan ${ }^{\mathrm{TM}}$ assay. No significant change of $\beta$ hCG mRNA expression was seen in the untreated control (Figure 2). Time- and dose-dependency studies showed that the highest number of copies was measured at the higher dose $(200 \mu \mathrm{g} / \mathrm{mL})$ after as little as $30 \mathrm{~min}$, whereas with the lower dose $(100 \mu \mathrm{g} /$ $\mathrm{mL}) 60 \mathrm{~min}$ were required. In both cases the increase was 


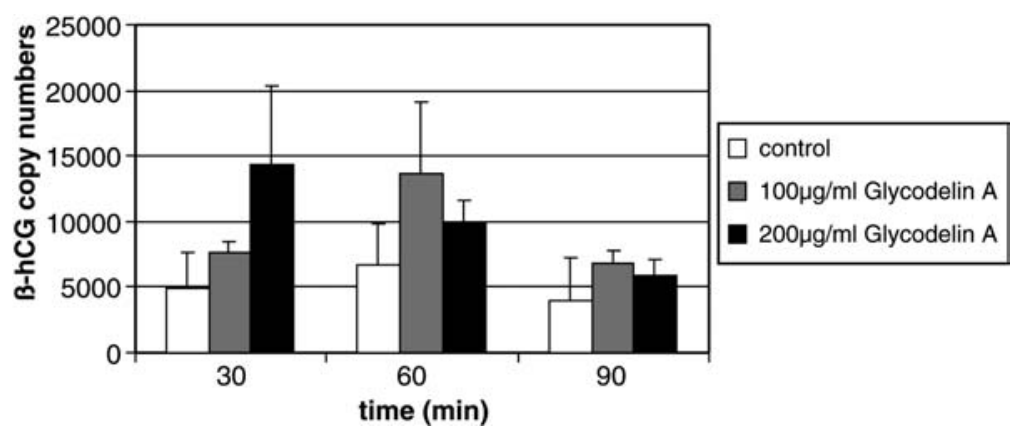

Figure 2 Time-dependent quantification of $\beta$ hCG mRNA copy numbers (mean values $\pm S D, n=3$ for every group) per 200 ng total mRNA in glycodelin A (100 $\mu \mathrm{g} / \mathrm{mL}, 200 \mu \mathrm{g} / \mathrm{mL})$ - treated or untreated trophoblast cell cultures. Quantification was performed using the external $\beta$ hCG RNA standard run in parallel.

statistically significant $(P=0.046$ and 0.028 , respectively). After 90 min, mRNA levels were almost indistinguishable from the controls.

\section{Stimulation of hCG protein production by glycodelin} A

The concentrations of hCG released by trophoblast cells, incubated for 24 or $48 \mathrm{~h}$ with different concentrations of glycodelin $A(0,50,100,200 \mu \mathrm{g} / \mathrm{mL})$ are shown in Figure 3. The data indicate that glycodelin A stimulates hCG protein production in trophoblast cells in a time and dose-dependent manner. When trophoblast cells were incubated with glycodelin A $(50 \mu \mathrm{g})$, no significant rise $(P=0.624)$ of hCG production was observed. A significant increase in hCG production was found for higher concentrations of glycodelin A $(100 \mu \mathrm{g} / \mathrm{mL} P=0.036$; $200 \mu \mathrm{g} / \mathrm{mL} \mathrm{P}=0.028$ ) after prolonged incubation (48 h). Addition of $100 \mu \mathrm{g} / \mathrm{mL}$ glycodelin A led to a rise of the hCG level by the factor 2.2, whereas addition of 200 $\mu \mathrm{g} / \mathrm{mL}$ led to a rise of the hCG levels by the factor 3.7. The transferrin containing fractions of amniotic fluid had no effect on the hCG production of trophoblast cells and showed the same values of hCG production as controls.

\section{Expression of hCG on CTB as detected by immunofluorescence}

Isolated trophoblast cells from the first trimester of pregnancy showed moderate expression of hCG after $72 \mathrm{~h}$ of cultivation and subsequent staining with the anti-hCG antibody MS-1039-P, respectively. Results are documented in Figure 4 A. Glycodelin A-treated trophoblast cells $(100 \mathrm{mg} / \mathrm{mL}, 200 \mu \mathrm{g} / \mathrm{mL})$ showed a stronger expression of hCG. The same set of antibodies was used as for investigations of controls. Results are documented in Figure 4 B,C. Slides incubated with normal mouse serum or monoclonal anti-GdA antibody A87-B/D2 showed no staining of cytotrophoblast cells (data not shown).

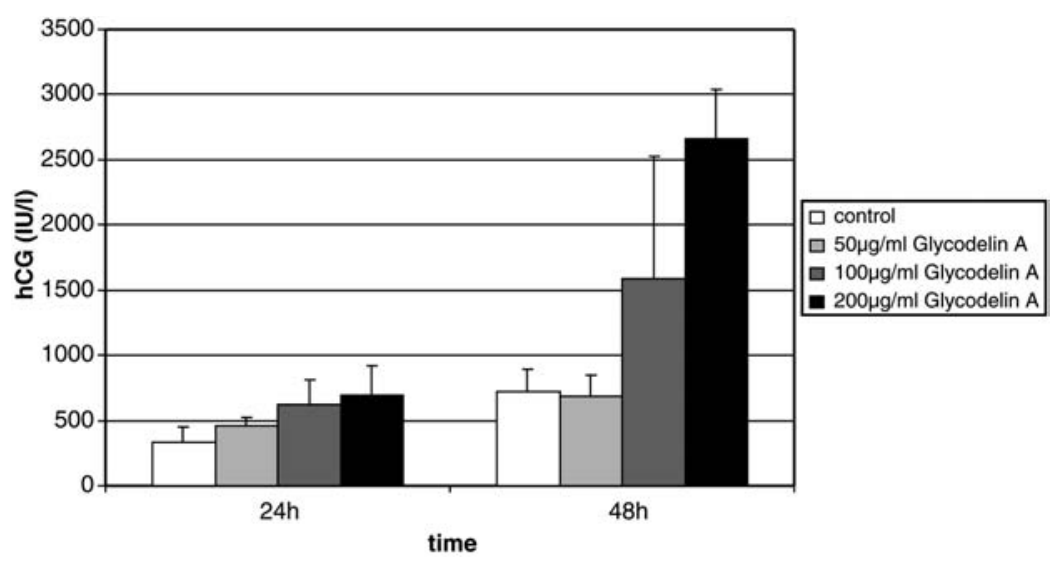

Figure 3 Effect of glycodelin A on the hCG production of cytotrophoblast cells in vitro. Data (mean \pm SD) represent hCG concentration in aliquots of the culture media at designated times ( $n=4$ for every group). $P=0.036(100 \mu \mathrm{g} / \mathrm{mL}$ glycodelin $A)$ and $P=0.028$ $(200 \mu \mathrm{g} / \mathrm{mL}$ glycodelin A) indicates the significance levels between controls and stimulated cultures. There was no significant difference observed between the hCG production of controls and cells stimulated with $50 \mu \mathrm{g} / \mathrm{mL}$ glycodelin $A(P>0.05)$. 


\section{Comment}

The physiological role of hCG during pregnancy is not completely understood. It is generally assumed that hCG production by the trophoblast stimulates progesterone secretion, thus contributing to the maintenance of the corpus luteum of pregnancy. Expression of hCG is detectable as early as at the eight cell stage of the devel-
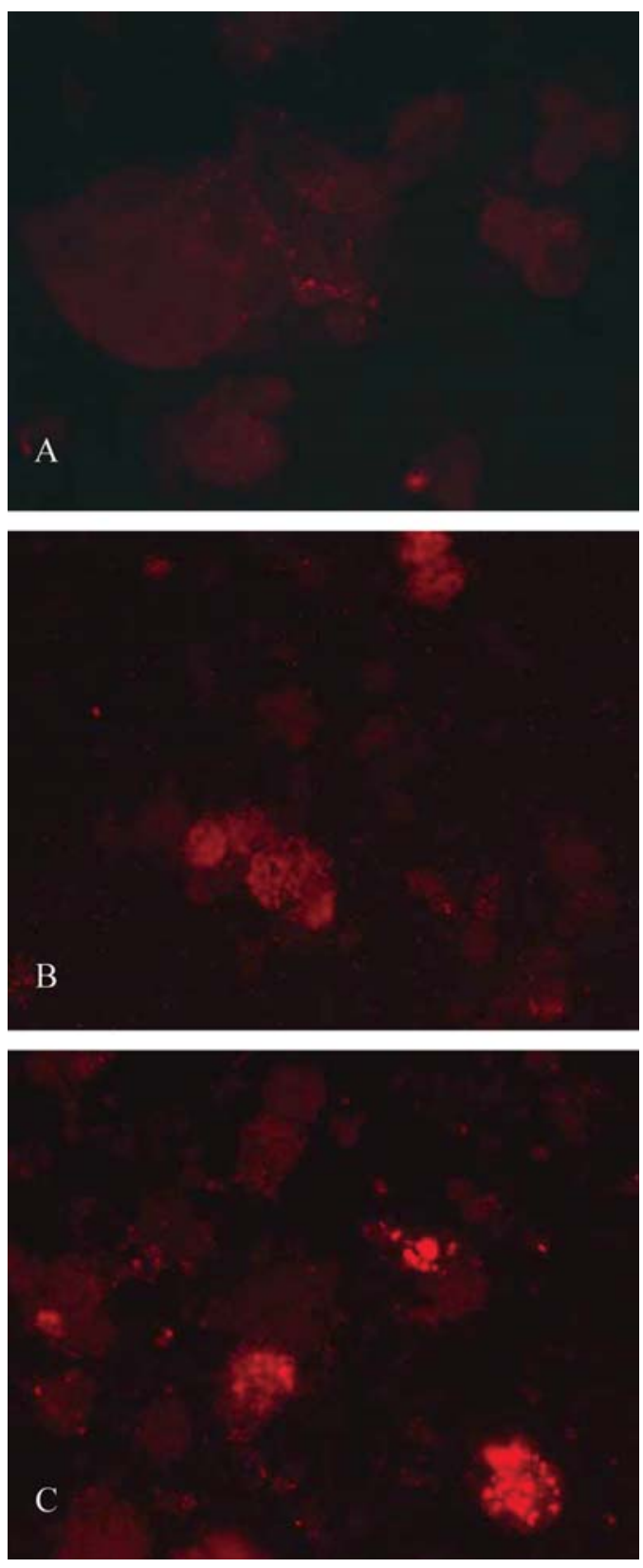

Figure 4 Expression of $\mathrm{hCG}$ on cytotrophoblast cells cultured without (A) or with $100 \mu \mathrm{g} / \mathrm{mL}$ glycodelin A (B) and $200 \mu \mathrm{g} / \mathrm{mL}$ glycodelin $A(C)$ after $72 \mathrm{~h}$ of incubation. Slides were stained for hCG (mab MS-1039-P). Second antibodies were Cy3- labelled, respectively. $63 \times$ lens. oping embryo [4]. An array of paracrine modulators of hCG synthesis has been identified [14, 18, 29, 33], but less is known about the regulatory elements of the hCG $\beta$ gene because highly differentiated cells are required for their regulation [1].

This study shows that glycodelin A stimulates hCG in isolated trophoblast cells in vitro at mRNA level. In addition, glycodelin A caused an increase in hCG release by cultivated cytotrophoblast cells into the medium. This increase was dose-dependent. Addition of $50 \mu \mathrm{g} / \mathrm{mL}$ glycodelin A did not lead to a significant increase of hCG secretion. Addition of higher concentrations $(100 \mu \mathrm{g} / \mathrm{mL}$ and $200 \mu \mathrm{g} / \mathrm{mL}$ ) of glycodelin $A$ induced a significant increase in secretion of hCG compared to unstimulated controls in trophoblast cells. The range of concentrations of glycodelin used for the experiments is similar to the physiological range of this glycoprotein as found in amniotic fluid during the first trimester of pregnancy [44]. The glycodelin concentration rises during the first eight to nine weeks of gestation, and is maintained until 14-15 weeks of gestation [21]. During this time of pregnancy, fetus-derived trophoblast cells invade deeply into the maternal decidua, and the contact between fetal and maternal cells is most intimate [9]. Glycodelin A is the main product of the decidua in the first trimester of pregnancy $[19,43]$, whereas also IGF-BP1 and prolactin are synthesized and secreted in high levels by decidual cells $[5,10,11,13,24,31,34,47,46]$. Our results suggest a stimulating effect of glycodelin A on hCG secretion of trophoblasts. To investigate a possible induction of hCG synthesis in trophoblasts by glycodelin A, real time RTPCR was used. The results showed a dose dependent stimulating effect of glycodelin A of trophoblasts on the $\beta$ hCG mRNA level. There was no significant rise of hCG $\beta$ mRNA in unstimulated controls. The addition of high amounts of glycodelin $A(200 \mu \mathrm{g} / \mathrm{mL})$ led to an immediate increase of $\beta$ hCG mRNA copy numbers by the factor 3 after only 30 min of incubation compared to unstimulated controls. Addition of $100 \mathrm{mg} / \mathrm{mL}$ glycodelin A led to an immediate increase of $\beta$ hCG mRNA copy numbers by the factor 2 after 60 min of incubation. This immediate stimulation effect was also observed in former studies, where glycodelin A stimulated $\beta$ hCG mRNA synthesis in term trophoblast cells [40] as well as in Jeg 3 trophoblast tumor cells [2]. A delayed stimulation of hCG protein production by glycodelin A was measured in both cell types, which could be explained by a feedback inhibition of the BhCG mRNA synthesis by hCG itself. Feedback inhibition of gene expression is a widespread phenomenon in which the expression of a gene is downregulated by its protein product. Feedback in eukaryotic cells involves time delays resulting from transcription, transcript splicing and processing, and protein synthesis [30].

Thus, our results show that glycodelin $A$ induces both $\beta$ hCG mRNA synthesis and secretion of hCG in trophoblast cells, although the exact mechanism of action of 
Table 1 Antibodies used in the study.

\begin{tabular}{lllll}
\hline Antigen & Clone & Species and isotype & Concentration/dilution & Source \\
\hline CD 45 & CBL 124 & Mouse IgG & $1: 100$ & Dianova \\
CD 9 & CBL 560 & Mouse IgG & $1: 100$ & Dianova \\
CK 7 & Ks 7.18 & Mouse IgG & $1: 50$ & Progen Biotechnik \\
Glycodelin & - & Rabbit IgG & $10 \mu \mathrm{g} / \mathrm{mL}$ & Bioscience \\
Glycodelin A & A87-B/D2 & Mouse IgG & $5 \mu \mathrm{g} / \mathrm{mL}$ & Nemod \\
hCG & MS-1039-P & Mouse IgG & $5 \mu \mathrm{g} / \mathrm{mL}$ & Dianova \\
TF & A78 G/A7 & Mouse IgM & $1: 4$ & Serotec \\
\hline
\end{tabular}

glycodelin A on trophoblast cells is not known. It is already known that glycodelin $A$ regulates uterine immune responsiveness. It has been shown that decidual extracts containing glycodelin A suppress thymidine uptake in normal and mitogen-stimulated human mixed lymphocyte cultures [37]. In addition, glycodelin A decreased the synthesis of IL1 and IL2 and the expression of the IL2-receptor by mitogen-stimulated cells [35, 36]. Here we showed that glycodelin $A$ is involved in stimulation of first trimester trophoblast derived glycoprotein hormone hCG. In a recently published study we could show that glycodelin $A$ induced a reduced expression of hPL in first trimester trophoblast cells. Expression of MUC1 was not affected by glycodelin A. Freshly isolated trophoblast cells showed no Thomsen-Friedenreich (TF) expression, a marker for the syncytiotrophoblast and extravillous trophoblast cells [15] but became positive for this antigen after $96 \mathrm{~h}$ of cultivation. Glycodelin A stimulated trophoblast cells inhibit TF-expression after $96 \mathrm{~h}$ of cultivation and glycodelin A plasmids induced a significantly higher hCG production in transfected cells compared to cells transfected with the empty plasmid [16]. Results obtained in both studies suggest that glycodelin $A$ is involved in differentiation of trophoblast cells. This is due to the fact that treatment of glycodelin $A$ and its plasmid transfected trophoblast cells stimulated hCG production in isolated first trimester trophoblast cells and inhibited hPL and TF expression.

In conclusion, we have shown that glycodelin A induces synthesis of $\beta$ hCG mRNA and secretion of hCG in trophoblast cells. These results indicate a function of glycodelin A in trophoblast hCG production. But more information about the exact mechanism of $\mathrm{hCG}$ regulation by glycodelin $A$ is required.

\section{Acknowledgements}

This research was supported by the "Deutsche Forschungsgemeinschaft" (DFG, JE 181/4-1).

\section{References}

[1] Albanese C, IM Colin, WF Crowley, M Ito, RG Pestell, J Weiss, JL Jameson: The gonadotropin genes: evolution of distinct mechanisms for hormonal control. Recent Prog Horm Res 51 (1996) 23

[2] Bergemann C, T Reimer, H Muller, A Hosel, V Briese, $\mathrm{K}$ Friese, $U$ Jeschke: Stimulation of hCG protein and mRNA levels in trophoblast tumour cells Jeg3 and BeWo by glycodelin A Anticancer Res 23 (2003) 1107

[3] Boime I: Human placental hormone production is linked to the stage of trophoblast differentiation. Tropho Res 5 (1991) 57

[4] Bonduelle ML, R Dodd, I Liebaers, A Van Steirteghem, R Williamson, $\mathrm{R}$ Akhurst: Chorionic gonadotrophin-beta mRNA, a trophoblast marker, is expressed in human 8-cell embryos derived from tripronucleate zygotes. Hum Reprod 3 (1988) 909

[5] Chao HS, SE Myers, S Handwerger: Endothelin inhibits basal and stimulated release of prolactin by human decidual cells. Endocrinology 133 (1993) 505

[6] Chomczynski P, N Sacchi: Single-step method of RNA isolation by acid guanidinium thiocyanate-phenol-chloroform extraction. Anal Biochem 162 (1987) 156

[7] Cole LA, S Shahabi, SA Butler, H Mitchell, ES Newlands, HR Behrman, HL Verrill: Utility of commonly used commercial human chorionic gonadotropin immunoassays in the diagnosis and management of trophoblastic diseases. Clin Chem 47 (2001) 308

[8] Dell A, HR Morris, RL Easton, M Panico, M Patankar, S Oehniger, R Koistinen, H Koistinen, M Seppala, GF Clark: Structural analysis of the oligosaccharides derived from glycodelin, a human glycoprotein with potent immunosuppressive and contraceptive activities. J Biol Chem 270 (1995) 24116

[9] Hammer A, A Blaschitz, C Daxbock, W Walcher, G Dohr: Fas and Fas-ligand are expressed in the uteroplacental unit of first-trimester pregnancy. Am J Reprod Immunol 41 (1999) 41

[10] Heffner LJ, LA Benoit, DR Clemmons, KC Copeland: The secretion of insulin-like growth factor I, prolactin and insulinlike growth factor binding protein 1 by the decidua as predictors of human fetal growth. Growth Horm IGF Res 8 (1998) 33

[11] Heffner LJ, BS Bromley, KC Copeland: Secretion of prolactin and insulin-like growth factor I by decidual explant cultures from pregnancies complicated by intrauterine growth retardation. Am J Obstet Gynecol 167 (1992) 1431

[12] Hoshina M, M Boothby, R Hussa, R Pattillo, HM Camel, I Boime: Linkage of human chorionic gonadotrophin and placental lactogen biosynthesis to trophoblast differentiation and tumorigenesis. Placenta 6 (1985) 163

[13] Irwin JC, L de las Fuentes, LC Giudice: Growth factors and decidualization in vitro. Ann N Y Acad Sci 734 (1994) 7

[14] Jameson JL, AN Hollenberg: Regulation of chorionic gonadotropin gene expression. Endocr Rev 14 (1993) 203 
[15] Jeschke U, DU Richter, A Hammer, V Briese, K Friese, U Karsten: Expression of the Thomsen-Friedenreich antigen and of its putative carrier protein mucin 1 in the human placenta and in trophoblast cells in vitro. Histochem Cell Biol 117 (2002) 219

[16] Jeschke U, DU Richter, T Reimer, C Bergemann, V Briese, U Karsten, I Mylonas, MS Kupka, I Wiest, K Friese: Glycodelin A and differentiation of first trimester trophoblast cells in vitro. Arch Gynecol Obstet (2004) DOI: 10.1007/s00404004-0682-2

[17] Jeschke U, DU Richter, H Walzel, C Bergemann, I Mylonas, $S$ Sharma, C Keil, V Briese, K Friese: Stimulation of hCG and inhibition of hPL in isolated human trophoblast cells in vitro by glycodelin A. Arch Gynecol Obstet 268 (2003) 162

[18] Johnson W, C Albanese, S Handwerger, T Williams, RG Pestell, JL Jameson: Regulation of the human chorionic gonadotropin alpha- and beta-subunit promoters by AP-2. J Biol Chem 272 (1997) 15405

[19] Julkunen M: Human decidua synthesizes placental protein 14 (PP14) in vitro. Acta Endocrinol (Copenh) 112 (1986) 271

[20] Julkunen M, R Koistinen, J Sjoberg, EM Rutanen, T Wahlstrom, M Seppala: Secretory endometrium synthesizes placental protein 14. Endocrinology 118 (1986) 1782

[21] Julkunen M, EM Rutanen, A Koskimies, T Ranta, H Bohn, M Seppala: Distribution of placental protein 14 in tissues and body fluids during pregnancy. Br J Obstet Gynaecol 92 (1985) 1145

[22] Julkunen M, M Seppala, OA Janne: Complete amino acid sequence of human placental protein 14: a progesteroneregulated uterine protein homologous to beta-lactoglobulins. Proc Natl Acad Sci U S A 85 (1988) 8845

[23] Koistinen H, R Koistinen, A Dell, HR Morris, RL Easton, MS Patankar, S Oehninger, GF Clark, M Seppala: Glycodelin from seminal plasma is a differentially glycosylated form of contraceptive glycodelin-A. Mol Hum Reprod 2 (1996) 759

[24] Kubota T, S Kamada, M Taguchi, T Aso: [The effects of insulin-like growth factor-I (IGF-I) and IGF-II on prolactin (PRL) release from human decidua and amniotic fluid circulation]. Nippon Sanka Fujinka Gakkai Zasshi 43 (1991) 1515

[25] Laird SM, TC Li, AE Bolton: The production of placental protein 14 and interleukin 6 by human endometrial cells in culture. Hum Reprod 8 (1993) 793

[26] Laird SM, E Tuckerman, TC Li, AE Bolton: Stimulation of human endometrial epithelial cell interleukin 6 production by interleukin 1 and placental protein 14. Hum Reprod 9 (1994) 1339

[27] Maston GA, M Ruvolo: Chorionic gonadotropin has a recent origin within primates and an evolutionary history of selection. Mol Biol Evol 19 (2002) 320

[28] Miller RE, JD Fayen, S Chakraborty, MC Weber, ML Tykocinski: A receptor for the lipocalin placental protein 14 on human monocytes. FEBS Lett 436 (1998) 455

[29] Mochizuki M, T Maruo, H Matsuo, T Samoto, N Ishihara: Biology of human trophoblast. Int J Gynaecol Obstet 60 Suppl 1 (1998) S21

[30] Monk NA: Oscillatory expression of Hes1, p53, and NFkappaB driven by transcriptional time delays. Curr Biol 13 (2003) 1409

[31] Nowak RA, MS Rein, LJ Heffner, AJ Friedman, AH Tashjian, Jr.: Production of prolactin by smooth muscle cells cultured from human uterine fibroid tumors. J Clin Endocrinol Metab 76 (1993) 1308

[32] Okamoto N, A Uchida, K Takakura, Y Kariya, H Kanzaki, L Riittinen, R Koistinen, M Seppala, T Mori: Suppression by human placental protein 14 of natural killer cell activity. Am J Reprod Immunol 26 (1991) 137

[33] Pestell RG, AN Hollenberg, C Albanese, JL Jameson: c-Jun represses transcription of the human chorionic gonadotropin alpha and beta genes through distinct types of CREs. J Biol Chem 269 (1994) 31090

[34] Pierro E, CL Andreani, N Lazzarin, F Minici, R Apa, F Miceli, G Ayala, S Mancuso, A Lanzone: Effect of anticardiolipin antibodies on prolactin and insulin-like growth factor binding protein-1 production by human decidual cells. Am J Reprod Immunol 41 (1999) 209

[35] Pockley AG, AE Bolton: Placental protein 14 (PP14) inhibits the synthesis of interleukin-2 and the release of soluble interleukin-2 receptors from phytohaemagglutinin-stimulated lymphocytes. Clin Exp Immunol 77 (1989) 252

[36] Pockley AG, AE Bolton: The effect of human placental protein 14 (PP14) on the production of interleukin-1 from mitogenically stimulated mononuclear cell cultures. Immunology 69 (1990) 277

[37] Pockley AG, EA Mowles, RJ Stoker, OM Westwood, MG Chapman, AE Bolton: Suppression of in vitro lymphocyte reactivity to phytohemagglutinin by placental protein 14 . J Reprod Immunol 13 (1988) 31

[38] Rachmilewitz J, GJ Riely, JH Huang, A Chen, ML Tykocinski: A rheostatic mechanism for T-cell inhibition based on elevation of activation thresholds. Blood 98 (2001) 3727

[39] Rachmilewitz J, GJ Riely, ML Tykocinski: Placental protein 14 functions as a direct T-cell inhibitor. Cell Immunol 191 (1999) 26

[40] Reimer T, D Koczan, V Briese, K Friese, D Richter, HJ Thiesen, $U$ Jeschke: Absolute quantification of human chorionic gonadotropin-beta mRNA with TaqMan detection. 4. Mol Biotechnol 14 (2000) 47

[41] Reimer T, D Koczan, H Muller, K Friese, A Krause, HJ Thiesen, B Gerber: Human chorionic gonadotrophin-beta transcripts correlate with progesterone receptor values in breast carcinomas. J Mol Endocrinol 24 (2000) 33

[42] Seppala M, M Julkunen, L Riittinen, R Koistinen: Endometrial proteins: a reappraisal. Hum Reprod 7 Suppl 1 (1992) 31

[43] Seppala M, AM Suikkari, M Julkunen: Human endometria proteins. Reprod Nutr Dev 28 (1988) 1649

[44] Seppala M, RN Taylor, H Koistinen, R Koistinen, E Milgrom: Glycodelin: a major lipocalin protein of the reproductive axis with diverse actions in cell recognition and differentiation. Endocr Rev 23 (2002) 401

[45] Shi QJ, ZM Lei, CV Rao, J Lin: Novel role of human chorionic gonadotropin in differentiation of human cytotrophoblasts. Endocrinology 132 (1993) 1387

[46] Thrailkill KM, A Golander, LE Underwood, S Handwerger: Insulin-like growth factor I stimulates the synthesis and release of prolactin from human decidual cells. Endocrinology 123 (1988) 2930

[47] Thrailkill KM, A Golander, LE Underwood, RG Richards, S Handwerger: Insulin stimulates the synthesis and release of prolactin from human decidual cells. Endocrinology 124 (1989) 3010

[48] Tomczak S, V Briese, S Kunkel, H Muller: Serum placental protein 14 (PP14) levels in patients with threatened abortion. Arch Gynecol Obstet 258 (1996) 165

Received July 20, 2004. Revised December 22, 2004. Accepted January 5, 2005 